\title{
A Logistic Regression Model Comparing Astronomy And Non-Astronomy Teachers In Québec's Elementary Schools
}

Pierre Chastenay, Université du Québec à Montréal, Canada Martin Riopel, Université du Québec à Montréal, Canada

\begin{abstract}
Based on the results of an online survey of 500 Québec's elementary (K-6) teachers conducted in 2015 that probed the way respondents teach astronomy to their classrooms, their background in $S \& T$, their pre-service education, their aims and goals for astronomy teaching, their attitude toward teaching astronomy, the resources and materials they use, their view on the effectiveness of pre- and in-service training, and their need for in-service training, we present a logistic regression model comparing elementary teachers in our survey that teach astronomy to their class ("Astronomy" teachers, $N=244$ ) and those who don't ("Non-astronomy" teachers, $N=256$ ), to reveal factors that seem to facilitate or hinder astronomy teaching in Québec's elementary classrooms. Based on the model, several ways to enhance the teaching of astronomy in Québec's K-6 classrooms are proposed: offer high-quality pre-and in-service training in astronomy to elementary teachers, raise the profile of science teaching in elementary schools, and help teachers realize the importance of teaching astronomy in their classrooms to cover the curriculum standards.
\end{abstract}

Keywords: Astronomy Education Research; K-12 Teachers; Attitudes

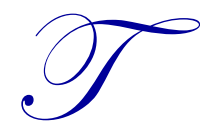

he teaching of astronomy at the elementary (K-6) and secondary (middle and high) school levels has been the subject of renewed interest throughout the world since the 1990s, particularly in the United States (American Association for the Advancement of Science (AAAS), 1990; Schleigh, Slater, Slater \& Stork, 2015; Slater \& Slater, 2015) and in Canada (Conseil des ministres de l'éducation du Canada (CMÉC), 1997). The introduction of astronomy in school curricula stems from a genuine interest demonstrated by young students for this particular topic (Jarman \& McAleese, 1996), and also reflects the recognition by curriculum developers that astronomy has its place in schools alongside the other sciences. With agriculture, astronomy is generally considered the oldest of the sciences (Trumper, 2006). A science of time and space, astronomy helps us measure and understand the great cycles that govern our lives - the diurnal cycle, phases of the Moon and the seasons - and tells us about our place on Earth and in the vast cosmos. For the historical and philosophical impact of astronomy, for its practical, technological and, of course, scientific contributions, for aesthetic and emotional factors related to the contemplation of the starry sky, and to help students better understand and appreciate science, its tools and processes, astronomy certainly has its place in the knowledge base that everyone should have when leaving school (Percy, 2005).

Following the international trend mentioned above, and recognizing the importance of teaching basic astronomical concepts in elementary and secondary schools, Québec's Ministry of Education introduced astronomy in the curriculum in the mid-2000s (Ministère de l'Éducation du Québec, 2006). It is important to note that astronomy was previously absent from Québec's elementary curriculum; only a few basic concepts like the diurnal cycle, the phases of the Moon and the seasons were addressed in the geography course in the first year of secondary (high) school (Thouin, 2015). The relatively recent introduction of astronomy in Québec elementary schools' curriculum thus raises the question of how do elementary teachers cope with this new topic. For instance, do elementary teachers feel competent enough to teach astronomy to their class? What is their level of satisfaction toward pre-service and inservice training in astronomy, when available? What material and resources do they use to teach astronomy? And why is it that some of them decide not to teach astronomy at all to their class, despite the topic now being part of the curriculum? 
To answer these questions, a little less than a decade after the introduction of astronomy in Québec's elementary classrooms, we conducted an online survey of elementary teachers to probe several aspects of astronomy teaching: the way elementary teachers teach astronomy to their class (or not), their background in science and technology (scientific leisure and pre-teaching employment in science), their pre-service training in astronomy, in science and in science education, their aims and goals for astronomy teaching, their attitude toward astronomy and astronomy teaching, the resources and materials they use, their view on the effectiveness of pre- and in-service training, and their perceived need for in-service training. These particular topics were chosen based partly on the research questions listed in the preceding paragraph, and partly on a literature review of past surveys conducted in Canada and the United States, to be described later.

In this paper, we will take advantage of the fact that our survey's sample $(\mathrm{N}=500)$ comprised an almost equal number of Astronomy $(\mathrm{N}=244)$ and Non-astronomy $(\mathrm{N}=256)$ teachers. This situation offers the possibility to statistically compare answers given by both groups to the survey questions by building a logistic regression model using Astronomy/Non-astronomy teacher as the binary dependent variable. The aim of the present study is thus to identify what seems conducive and what seems to hinder astronomy teaching in Québec's elementary classrooms, based on such a model.

In the first section of this paper, we will review past surveys that probed science and astronomy teachers in Canada and the United States. These surveys informed the theoretical framework as well as many practical aspects of the construction of our own survey. Then, we will present a brief description of the survey instrument used in the present study, as well as a summary of the major findings of the survey already presented in Chastenay (2018). Finally, we will describe the construction of a logistic regression model comparing Astronomy and Non-astronomy teachers and present the major results. In conclusion, we will propose a series of recommendations, based on the model, to improve and enhance the teaching of astronomy in Québec's elementary schools, hoping that these proposals will be of use for science educators, teachers' trainers and curriculum developers in other parts of the world as well.

\section{PAST SURVEYS OF SCIENCE TEACHERS IN CANADA AND THE US}

Our study follows several surveys conducted in Canada and the United States in the past decades that probed elementary, middle, and high school teachers about their practice of astronomy and science teaching: Krumenaker (2008, 2009a, 2009b); Plummer and Zahm (2010); Sadler (1992); Slater, Slater, and Olson (2009). We chose to concentrate on studies conducted in Canada and the US because of the similarities between school organizations in both countries, allowing valid comparisons between jurisdictions. To the best of our knowledge, no such study has ever been conducted in Québec. In this section, we will report major findings from two large surveys that are more closely aligned with our own and provide the best theoretical and practical basis for our research: Rowell and Ebbers (2004), and Banilower et al. (2013).

In their study, Rowell and Ebbers (2004) surveyed 1,116 elementary science teachers in Alberta, Canada, using a mailed paper-and-pencil questionnaire enquiring about several components of science teaching at the elementary level. Questions included demographics, the teachers' goals in teaching science, their background and experience, the resources and material they used, the abilities and interests of their students, and the support they received from their school.

The authors found that Alberta's elementary teachers are mostly female, aged 35 years and older, with more than 10 years of experience teaching at the elementary level. The majority hold a Bachelor's degree, did not study science nor technology after completing High school, and have had no science or technology-related job before of after becoming an elementary teacher. Alberta teachers reported that the main obstacles to science teaching were insufficient school facilities and arrangements (for example, not enough time for science teaching in the class schedule), inadequate physical facilities (small classroom), and lack of teaching equipment. Also, Rowell and Ebbers (2004) found that elementary teachers teach science mainly through the use of reading material (textbooks and exercise books). As far as in-service training is considered, it is considered mostly ineffective or non-existent for elementary teachers surveyed and, when available, typically consists of informal conversations between colleagues. 
Another similar survey was conducted in the United States in 2012: the National Survey of Science and Mathematics Education (NSSME) (Banilower et al., 2013). This survey of 7,752 elementary, middle, and high schools teachers across the United States pursued many goals, such as studying teachers' background and attitudes toward science teaching, their professional development in science, the way they made instructional decision, their objectives, resources, and the factors that affected the way they teach. The NSSME results show that elementary teachers' content preparation in science is rather light, and that they feel ill prepared to teach science. Banilower and his colleagues link this situation to the fact that very few elementary teachers have studied science as undergraduates. They also concede that staying current in science is particularly difficult for elementary teachers that typically teach multiple subjects, and also because of the relative scarcity of in-service training in science offered to them.

The NSSME also discovered that elementary teachers teach science less longer and with longer intervals between lessons than other subjects, like reading/language arts and mathematics. Science is taught almost every day in only $20 \%$ of K-3 classrooms and in 35\% of 4-6 classrooms, compared to $99 \%$ and $98 \%$ respectively for math. Many elementary students are taught science only a few days a week, or only during a few weeks during the school year. Science is taught on average only 19 minutes per day in grades K-3, and only 24 minutes per day in grades 4-6, compared to 89 and 83 minutes per day for reading/language arts respectively, and 54 and 61 minutes per day for math. The use of science specialists, either to replace or in addition to the regular classroom teacher, is infrequent in elementary schools.

The NSSME also found that the use of a science textbook or other reading material is more likely in elementary schools than in high school. Sixty-nine percent of elementary classes use textbooks in science, and teachers declare that they mostly use science textbooks to plan their teaching. Similar results about the use of textbooks in science teaching were found by Kesidou and Roseman (2002) and Hasni, Moreseli, Samson, and Owen (2009).

A majority of science teachers who completed the NSSME survey rated their resources in science as poor. The budget spent on instructional resources in science also seems inadequate, especially when evaluated as a per-student spending. The situation is especially grim in science in the elementary grades, where per-student expenditure is about half of that spent in middle schools and less than one-third of what is spent in high schools. Funds for purchasing equipment and supplies is also lacking in elementary schools. Teachers also complain about a lack of science facilities in the school, insufficient time to teach science in the class schedule, and poor or non-existent professional development opportunities in science for teachers.

The situation described above, based on Rowell and Ebbers (2004) and Banilower et al. (2013) results, is quite similar to the situation we find in Québec's elementary schools (see Chastenay, 2018). We now hope to be able to draw a clearer picture of the state of astronomy teaching in Québec's schools by constructing a logistic regression model based on the data collected by our survey instrument, described next.

\section{SURVEY INSTRUMENT}

Our original survey instrument is mostly based on Rowell and Ebbers' survey, which is itself based on the Science Council of Canada's National Study of Science Education (NSSE), conducted in the early 1980s (viz. Orpwood \& Alam, 1984). One component of this vast study was a survey of elementary and secondary teachers addressing the following eight areas of interest in relation to science teaching:

- General information (age, gender, years of experience);

- Aims of science education (curriculum and instruction);

- Teacher's background and experience (pre- and in-service);

- Curriculum resources available/used (ministry guidelines, textbooks, etc.);

- Physical facilities and equipment;

- Institutional arrangements (time allocated to science teaching, teaching load, etc.);

- Students abilities, profiles and interests;

- Community and professional support. 
Since the goal of our survey was similar to the Science Council of Canada's NSSE, we adapted and expanded these eight areas of interest (including the use of online resources, which was still futuristic in the 1980s) to create a 35question survey that probed several facets of teaching astronomy at the elementary level. Our questions touched upon the following aspects of astronomy teaching: Demographics (age, gender); teaching experience; pre-service education and training in science and technology; pre-teaching science and technology-related employment experience; astronomy and science teaching experience; number of hours per week of science teaching; demographics and socioeconomic information about the school, classroom, and students; perceived efficiency of pre- and in-service training in astronomy, in science and technology, and in science teaching; perceived need for in-service training in astronomy; and self-interest in teaching astronomy.

The survey questions were ordered along two major axes, one individual and the other temporal: questions went from the personal to the professional realms of a teacher's life, as well as from the past (before becoming a teacher), to the actual teacher's condition, and also to what would be desirable in terms of future experiences. Thus, the first items in the survey were more personal and looking back, targeting demographic issues, past formation, past experiences in science and in astronomy, then encompassed the actual professional situation of the teacher (class level and class type, number of students in the classroom, school's location, etc.). The next series of questions were a sub-set of the survey addressed specifically to elementary teachers that presently teach astronomy in their classroom: Integration of astronomy with other school topics (French, English, Math, etc.); astronomical topics taught; number of hours per year devoted to astronomy teaching; aims and goals of teaching astronomy; classroom arrangements, resources and equipment available; and perceived difficulties and obstacles to teaching astronomy. Finally, the last questions of the survey considered the teachers' training continuum from past to future, probing all respondents (astronomy as well as non-astronomy teachers) about their pre-service and in-service training, and their perceived need for future training in astronomy.

The initial version of the survey was first tested with several university colleagues (science education specialists) and six volunteer elementary teachers that do teach astronomy to their class, to ensure a high level of readability and understanding of the questions and suggested answers. The elementary teachers were also able to confirm that questions appropriately covered all aspects of their own daily experience of teaching science and astronomy in elementary classrooms, and made suggestions where needed. This version was then field-tested face-to-face with elementary teachers participating in a two-day professional meeting of the Association québécoise des enseignantes et des enseignants du primaire (AQEP), held December 12 and 13, 2013, in Québec City. Respondents were asked to answer questions by tapping their preferred answer on an iPod screen; the survey took about 10 minutes to complete and 138 elementary teachers completed it (see Chastenay, 2014, for preliminary results). The survey was then slightly modified in light of these results, and it became the online survey that we report upon in this paper (see Chastenay (2018) for a list of questions used in the online survey).

The online survey (in French only) was conducted from January to March, 2015. Invitations to participate were sent via several channels: direct emails, Facebook pages, professional newsletters, etc. Since invitations were sent in French only (the language spoken by the majority of the population in Québec), we do not believe that language was an issue in understanding the survey questions. A total of 701 individuals logged on the survey's welcome page and began answering questions, and 500 completed the 35 questions. We compared all IP addresses collected by the survey instrument (LimeSurvey) and found no duplicates, indicating that all respondents were probably unique visitors. It is worth noting that the majority of the 201 individuals who did not complete the survey answered "No" to question 15 ("Did you teach any astronomy topic to your class during the last school year?"), and went no further. Although the invitation messages and the survey's welcome page insisted that even elementary teachers who do not teach astronomy were firmly invited to complete the survey nonetheless, it seems that a lot of them chose not to go beyond the admission that they did not teach astronomy to their class. This anecdotal information leads us to believe that the fraction of elementary teachers in our survey who do not teach astronomy is probably underestimated (or, to say it differently, "Astronomy teachers" are probably over represented in our sample). Of course, since ours is a convenience sample, we cannot pretend that our results are a statistically perfect illustration of the situation of astronomy teaching in Québec's schools. Nonetheless, with 500 respondents, we can clearly see patterns and trends emerging from our results; we will describe and analyze them in the following section. 


\section{MAJOR RESULTS OF THE SURVEY}

In this section, we briefly present the major results of our survey; see Chastenay (2018) for a more in-depth analysis of answers provided by elementary teachers. Our results show that the demographics of our sample is very similar to the general population of elementary school teachers in Québec (29,899 elementary teachers in 2014-2015), as described by Québec's Ministère de l'Éducation, de l'Enseignement supérieur et de la Recherche [MÉESR] demographic data (MÉESR, 2015): respondents are mostly female (91\%), aged around 40 years old ( $M=40.2$ years, $S D=8.9)$, and cumulating about 16 years of experience teaching at the elementary level $(M=15.6, S D=7.9)$. All respondents hold a four-year Bachelor's degree in Education, the minimum required in Québec to obtain a teaching license, but only $18 \%$ hold a higher degree (M.Ed. or Ph.D.). The schools where they teach, their socioeconomic status and geographical locations, the type of classroom, and their students' makeup, all are representative of Québec's typical elementary school, according to available census data (MÉESR, 2015).

Very few respondents to our survey have had a pre-teaching job experience in a science-related environment (8\%); for those who did, it was mostly in science museums. Preferred science-related leisure activities are watching and listening to science TV and radio shows (76\%), and visiting scientific web sites (55\%). For most of our survey's respondents, the study of science, like physics, chemistry or biology, didn't go beyond high school. The vast majority of respondents teach science only about one hour per week $(M=1.2$ hour, $S D=0.8)$, and $51 \%$ admit they don't teach astronomy at all in their classroom.

Respondents who said they teach astronomy to their class (49\%) seem to cover the topics contained in Québec's elementary schools curriculum well, even though the majority of Astronomy teachers devote only about 10 hours per year to this subject $(M=10.3$ hours, $S D=6.7)$. Their aims and goals in astronomy teaching are well aligned with Québec's school program objectives, which are to help students develop their competencies and learn core knowledge in astronomy. But astronomy teachers admit that they meet with a lot of difficulties when teaching astronomy: lack of resources and materials, old equipment of poor quality, lack of pre- and in-service training, inadequate classroom arrangement, not enough time in the class schedule, as well as their own feeling of being incompetent to teach the subject adequately.

A telling result is the choice of Internet (93\%), trade books (70\%), textbooks (53\%), and other reading material like newspapers and magazines (38\%) as the tools used by the majority of Astronomy teachers to teach astronomy. This tends to show that astronomy teaching in Québec's elementary schools is mostly done through reading and writing activities, a result that is congruent with similar findings by Hasni et al. (2009) concerning the teaching of science in Québec schools.

Pre-service training in astronomy was unavailable for the majority of respondents to this survey (59\%); given the age group of the majority of elementary teachers who completed the survey (around 40 years old), most respondents had already completed their pre-service training well before astronomy was introduced in Québec's elementary school curriculum. What is more worrying is the very low level of satisfaction with pre-service training in science (59\%) and in science teaching (55\%). Also troubling is the fact that in-service training in astronomy is unavailable for $59 \%$ of respondents or, when available, seems to be mostly ineffective, even though the majority of respondents think they would need only a relatively short period of training time $(M=6.5$ hours, $S D=5.2)$ to feel competent enough to teach the topic in class.

These last results might help explain why about $17 \%$ of all respondents surveyed admit they would rather not teach astronomy at all to their class, if given the choice. The reasons they provide are congruent with what we wrote previously about the difficulties of teaching astronomy in elementary school, like the absence or the poor quality of pre-service and in-service training, and also the fact that astronomy is not mandatory at the elementary level in Québec's schools. A lot of teachers admit they prefer to devote more class time to core subjects, like French and Math, which are incidentally the subject of two mandatory, province-wide Ministry of Education tests at the end of elementary school (cycle 3, grades 5 and 6). No such test exists in Québec's elementary schools for science and astronomy. 


\section{A LOGISTIC REGRESSION MODEL TO COMPARE ASTRONOMY AND NON-ASTRONOMY TEACHERS}

Since our survey sample contains an almost equal number of Astronomy $(\mathrm{N}=244)$ and Non-astronomy $(\mathrm{N}=256)$ teachers, it offers the opportunity to statistically compare answers from both groups to all questions in our survey, except questions 16 to 25 that were answered by Astronomy teachers only (see Chastenay, 2018). To make this comparison, we chose to build a logistic regression model that will reveal factors that are conducive or hinder the teaching of astronomy at the elementary level in Québec schools. We describe the details of the model construction in this section. Other statistical methods, like factor analysis or principal component analysis, were not favored for the simple reason that the survey was not constructed to be used with such approaches: each question in the survey was designed to measure a single dimension of astronomy teaching at the elementary level, hence there is very little correlation between variables that could lead to latent factors emerging from the data. Since our goal is basically to reveal factors that explain membership in one of two groups (Astro vs Non Astro), logistic regression is the method of choice.

\section{Assumptions of Logistic Regression}

Logistic regression is a form of regression that fits a model to data, based on one or several predictors (independent variables, categorical or continuous), to predict the outcome of a binary dependent variable (in the present case, to teach astronomy at the elementary level or not). Logistic regression is the method of choice when linear regression cannot be used because of the binary nature of the dependent variable (see Peng, Lee, and Ingersoll (2002) for a general discussion of the mathematical basis of logistic regression). That being said, logistic regression shares several assumptions with normal regression, namely: linearity between the outcome and the continuous predictor variables (although in the case of logistic regression, we use the natural logarithm, or logit, of the continuous variables); independence of errors (case data are not related, which is the case in this survey, since each respondent answered only once); and no multicollinearity is present (in other words, predictor variables are not too highly correlated) (Field, 2018). Also, data must be present for all combinations of the predictor variables (a condition known as complete information), and the outcome variable must not be perfectly predicted by one or a combination of predictors (i.e. complete separation). Before we create the logistic regression model, we will verify these assumptions in the following sections, using IBM's SPSS statistical software package (version 24.0).

\section{Empty Cells}

First, to check for empty cells, we produced multiway crosstabulations of all categorical independent variables (note that all continuous variables in our model have normal distributions and are thus not subject to this condition). We also verified that expected frequencies in each cell were greater than 1 , and that no more than $20 \%$ of expected frequencies were less than 5 , both necessary conditions to ensure the goodness-of-fit of the logistic regression model (Howell, 2006). Inability to meet these criteria may result in loss of statistical power. We report problematic variables below.

The variable Sex had to be rejected from the model because, in crosstabulations with other categorical variables, we found too many empty cells or cells with expected frequencies less than 1 (for example, with the variable Last Course in Physics \& Chemistry). This is due to the fact that our sample is mainly composed of women (men represent only $9 \%$ of the sample). As we have seen previously, this is also true for the general population of Québec's elementary teachers (MÉLS, 2015). Other predictor variables that had to be rejected for the same reasons are Highest Diploma Obtained, Last Course in Math, School's ISEB', School's Location, Science Specialist at School, and Preferred Moment for In-service Training in Astronomy.

\footnotetext{
${ }^{1}$ The Index of socio-economic background (ISEB, IMSE for the French acronym) is composed of two variables, the level of education of the mother and the unemployment rate of the parents, which emerged as the strongest predictors of children's academic difficulties (Ministère de l'Éducation, du Loisir et du Sport, 2014).
}

Copyright by author(s); $\underline{\text { CC-BY }}$ 


\section{Multicollinearity}

Next, we checked for multicolinearity between predictor variables (except those rejected in the previous step). Since we have continuous as well as categorical variables, a recommended first step to explore colinearity between variables is to run a crude linear regression including all predictor variables (forced entry, see Field, 2018) and to look for Tolerance statistic values less than 0.1 (Menard, 1995) or values of the Variance Inflation Factor (VIF) statistic equal to or larger than 10 (Myers, 1990), both indicating potential problems of multicolinearity. We found Tolerance values between .317 and $.930(M=.679)$, and VIF values between 1.076 and $3.153(M=1.700)$. Consequently, there is no obvious sign of multicolinearity in our data at this point: the smallest Tolerance value is .317 , well above .1 , and the largest VIF value is 3.153 , well below 10 . What's more, the mean VIF is marginally larger than 1 , which indicates that the regression is unbiased (Bowerman \& O'Connell, 1990).

To complete the analysis, we also looked at variance proportions associated with the eigenvalues of each predictor. We are looking for predictors that have high proportions of their variance on the same small eigenvalue, indicating that the variances of their regression coefficients are somewhat dependent. In the case of our model, we find signs of colinearity between Age and Years of Teaching Experience in Elementary School; between Last Course in Physics and Chemistry and Last Course in Biology; and also between Last course in History and Last Course in Geography. We also find signs of colinearity between Satisfaction Toward Pre-service Training in Astronomy, Satisfaction Toward Pre-service Training in Science and Satisfaction Toward Pre-service Training in Science Teaching. To follow up on this colinearity analysis, we went a step further by calculating proper correlation coefficients between predictors that were previously identified as possibly collinear (Pearson's $r$ between continuous variables and Cramer's V for categorical data). Table 1 presents the results.

Table 1. Correlation Coefficients between collinear variables

\begin{tabular}{|c|c|c|c|}
\hline Predictor Variable 1 & Predictor Variable 2 & $\begin{array}{c}\text { Correlation } \\
\text { statistics }\end{array}$ & Value \\
\hline Age & $\begin{array}{l}\text { Years of Experience Teaching in Elementary } \\
\text { School }\end{array}$ & Pearson's r & $.803^{* *}$ \\
\hline $\begin{array}{l}\text { Satisfaction Toward Pre-service Training in } \\
\text { Astronomy }\end{array}$ & $\begin{array}{l}\text { Satisfaction Toward Pre-service Training in } \\
\text { Science }\end{array}$ & Pearson's r & $.453^{* *}$ \\
\hline $\begin{array}{l}\text { Satisfaction Toward Pre-service Training in } \\
\text { Science }\end{array}$ & $\begin{array}{l}\text { Satisfaction Toward Pre-service Training in } \\
\text { Science Teaching }\end{array}$ & Pearson's r & $.735^{* *}$ \\
\hline $\begin{array}{l}\text { Satisfaction Toward Pre-service Training in } \\
\text { Astronomy }\end{array}$ & $\begin{array}{l}\text { Satisfaction Toward Pre-service Training in } \\
\text { Science Teaching }\end{array}$ & Pearson's r & $.420^{* *}$ \\
\hline Last Course in Physics \& Chemistry & Last Course in Biology & Cramer's V & $.504^{* *}$ \\
\hline Last Course in History & Last Course in Geography & Cramer's V & $.700^{* *}$ \\
\hline
\end{tabular}

** $\mathrm{p}<.01$

Table 1 quantitatively confirms the results of the exploratory linear regression for collinearity conducted before. Results show that there is a strong, positive correlation (larger than .5, see Cohen, 1988) between Age and Years of Teaching Experience in Elementary School (obviously, these two predictors evolve at the same rate and are clearly related), as well as between Satisfaction Toward Pre-service Training in Science and Satisfaction Toward Pre-service Training in Science Teaching (two subjects often taught together in Québec's teachers preparatory schools, sometimes in the same course). Correlation is moderate and positive between Satisfaction Toward Pre-service Training in Astronomy and both Satisfaction Toward Pre-service Training in Science and Satisfaction Toward Pre-service Training in Science Teaching. Finally, there is moderate and positive correlation between Last Course in Physics \& Chemistry and Last Course in Biology (these courses are often taken together by high school students enrolled in a science program), and strong correlation between Last Course in History and Last Course in Geography (again, these courses are often taken together by students enrolled in a humanities program). 
Because these correlations might add too much colinearity to our model, it is best to reject one of each correlated variables; otherwise we will not meet an important assumption of logistic regression. Since collinear and correlated variables are essentially redundant in our model, having the same effect on the outcome variable (all correlations are positive), we can safely proceed by keeping only one of each (Field, 2018). In our logistic regression model, we will thus keep the independent variable Years of Teaching Experience in Primary School instead of Age, since it is a more representative factor than age to assess a teacher's experience. We will also retain Last Course in Physics \& Chemistry instead of Last Course in Biology, since physics is more closely related to astronomy than biology, and Last Course in History instead of Last Course in Geography, since history, in contrast to the natural sciences, is more representative of studying the humanities than geography is. We will also retain Satisfaction Toward Pre-service Training in Science Teaching instead of Satisfaction Toward Pre-service Training in Science (the former having a slightly smaller correlation factor with Satisfaction Toward Pre-service Training in Astronomy than the latter). But we definitely want to keep the variable Satisfaction Toward Pre-service Training in Astronomy, even though there's a moderate correlation with Satisfaction Toward Pre-service Training in Science Teaching, since it will very likely be a central variable of our model. At the end of the process, we will be able to test for residuals and see if there remains too much multicolinearity in our model because of this inclusion.

\section{Linearity}

Finally, we verified that the outcome binary variable Astro vs Non Astro had a linear relationship with the natural logarithm of the continuous predictor variables that were not rejected in the previous steps. To do this, we ran a logistic regression (forced entry) including new predictors that represent the interaction between continuous variables and their own natural logarithm. Continuous variables included in the logistic regression model to test this assumption were Years of Teaching Experience in Elementary School, Number of Students in the Classroom, Number of Hours of Science Teaching per Week, Satisfaction Toward Pre-service Training in Astronomy, Satisfaction Toward Preservice Training in Science Teaching, Number of Hours of In-service Training Needed, and Efficacy of In-service Training in Astronomy. Results show that the Wald statistics were not significant $(p>.05)$ for all interactions, indicating that the assumption of linearity of the natural logarithm of these variables with the binary dependent variable has been met for all continuous variables in the model.

\section{Choosing the Independent Variables in the Model}

The next question we need to answer before proceeding with the logistic regression is whether all the remaining variables have their place in the model or not, since we wish to be able to determine with the greatest accuracy possible, but also with the most parsimonious model, the odds that, given an elementary teacher's answers to the questions associated with these variables, he or she will opt to teach astronomy in his or her classroom or not. To answer this question, we must now turn to theory and previous research on the teaching of astronomy in elementary schools. As we have stated before, this is the first study of its kind to be conducted in Québec, so there is no previous research in the province for us to base our reflection upon. We briefly presented in the introduction of this paper two important studies conducted in Alberta and in the United States whose conclusions will help us to choose the most promising variables to build our model. Table 2 briefly presents the justifications for the inclusion or rejection of each remaining predictor variable. 
Table 2. Variables considered for inclusion in the logistic regression model, with justifications based on results by Rowell and Ebbers (2004) and Banilower et al. (2013)

\begin{tabular}{|c|c|c|}
\hline Predictor Variable & $\begin{array}{l}\text { Expected effect direction of } \\
\text { the variable on the outcome }\end{array}$ & Justification for inclusion or rejection \\
\hline $\begin{array}{l}\text { Years of Teaching } \\
\text { Experience in Elementary } \\
\text { School }\end{array}$ & + or - & $\begin{array}{l}\text { More experienced teachers might feel more comfortable } \\
\text { teaching astronomy in their classroom, or they might prefer } \\
\text { not to teach it, since it was not included in their pre-service } \\
\text { training when they were university students }\end{array}$ \\
\hline $\begin{array}{l}\text { Last Course in Physics \& } \\
\text { Chemistry }\end{array}$ & + & $\begin{array}{l}\text { Teachers with higher degrees with course in physics and } \\
\text { chemistry, having studied science longer, might be more } \\
\text { familiar with the natural sciences and astronomy }\end{array}$ \\
\hline Last Course in History & - & $\begin{array}{l}\text { Teachers with higher degrees with course in history, having } \\
\text { studied the humanities longer, might be less familiar with the } \\
\text { natural sciences and astronomy }\end{array}$ \\
\hline Class Level & + & $\begin{array}{l}\text { In Québec's curriculum for elementary schools, astronomy } \\
\text { topics are covered in cycles } 1,2 \text { and } 3 \text { (grades } 1 \text { to } 6 \text { ), so we } \\
\text { expect that more teachers at these levels will teach astronomy } \\
\text { compared to kindergarten }(\mathrm{K})\end{array}$ \\
\hline $\begin{array}{l}\text { Number of Students in the } \\
\text { Classroom }\end{array}$ & Not included & $\begin{array}{l}\text { In Québec, class size often varies with the number of children } \\
\text { with disabilities or learning difficulties it includes, hence class } \\
\text { size could be a good indicator of the challenge of teaching } \\
\text { science and astronomy to these children; but several other } \\
\text { factors that have nothing to do with these difficulties influence } \\
\text { class size, like teaching in a rural or remote area with fewer } \\
\text { children. We thus prefer to exclude this variable and } \\
\text { concentrate on Class Type instead (see below) }\end{array}$ \\
\hline Class Type & - & $\begin{array}{l}\text { Teachers in classrooms that comprise children in poor } \\
\text { socioeconomic conditions and/or with disabilities might prefer } \\
\text { to concentrate on core subjects, like French and math, at the } \\
\text { expense of science and astronomy teaching }\end{array}$ \\
\hline Teaching Part Time & - & $\begin{array}{l}\text { Part-time teachers might be more likely than full-time } \\
\text { colleagues to concentrate on core subjects, like French and } \\
\text { math, at the expense of science and astronomy teaching }\end{array}$ \\
\hline $\begin{array}{l}\text { Number of Hours of Science } \\
\text { Teaching per Week }\end{array}$ & + & $\begin{array}{l}\text { Teachers more familiar with science teaching and doing more } \\
\text { science in their classrooms every week might also teach more } \\
\text { astronomy }\end{array}$ \\
\hline $\begin{array}{l}\text { Satisfaction Toward Pre- } \\
\text { service Training in } \\
\text { Astronomy }\end{array}$ & + & $\begin{array}{l}\text { Teachers having received more satisfactory pre-service } \\
\text { training in astronomy might teach more astronomy in their } \\
\text { classrooms }\end{array}$ \\
\hline $\begin{array}{l}\text { Satisfaction Toward Pre- } \\
\text { service Training in Science } \\
\text { Teaching }\end{array}$ & + & $\begin{array}{l}\text { Teachers having received more satisfactory pre-service } \\
\text { training in science teaching might teach more astronomy in } \\
\text { their classrooms }\end{array}$ \\
\hline Previous Science Job & + & $\begin{array}{l}\text { Teachers having more experience with science in the context } \\
\text { of pre-teaching employment might teach more astronomy in } \\
\text { their classroom }\end{array}$ \\
\hline $\begin{array}{l}\text { Participation in Science } \\
\text { Leisure Activity }\end{array}$ & + & $\begin{array}{l}\text { Teachers participating in more science leisure activities might } \\
\text { teach more astronomy in their classroom }\end{array}$ \\
\hline $\begin{array}{l}\text { Participation in In-service } \\
\text { Training in Astronomy }\end{array}$ & + & $\begin{array}{l}\text { Teachers participating in more in-service training in astronomy } \\
\text { might teach more astronomy in their classroom }\end{array}$ \\
\hline $\begin{array}{l}\text { Number of Hours of In- } \\
\text { service Training Needed }\end{array}$ & - & $\begin{array}{l}\text { Teachers feeling that they need longer in-service training in } \\
\text { astronomy might teach less astronomy in their classroom }\end{array}$ \\
\hline $\begin{array}{l}\text { Efficacy of In-service } \\
\text { Training in Astronomy }\end{array}$ & + & $\begin{array}{l}\text { Teachers feeling that they received efficient in-service training } \\
\text { in astronomy might teach more astronomy in their classroom }\end{array}$ \\
\hline $\begin{array}{l}\text { Prefer not to Teach } \\
\text { Astronomy }\end{array}$ & - & $\begin{array}{l}\text { Teachers preferring not to teach astronomy in their classroom } \\
\text { might in fact teach less astronomy }\end{array}$ \\
\hline
\end{tabular}


In summary, after removing variables that do not comply with the complete information assumption, and those that are too strongly correlated, after checking that there is indeed a linear relationship between the binary dependent variable and the natural logarithm of the continuous independent variables, and finally choosing among the remaining variables which ones will be retained in the model, we are left with 15 predictor variables (see Table 2), each associated with a single question of the survey of Québec's elementary teachers, to build our logistic regression model. Hosmer and Lemeshow (1989) and Cohen (1992) suggest that the minimum sample size for a logistic regression should be 10 times the number of predictors, which amounts to 150 in our case. Since our sample is $N=500$, that places us well above the minimum threshold recommended. We can thus proceed with the logistic regression.

\section{The Logistic Regression Model}

Table 3 presents the complete logistic regression model (forced entry). It allows us to correctly classify $74.9 \%$ of teachers in our sample, with a significance level given by a Pseudo $\mathrm{R}^{2}$ of .273 . This last figure is an estimate of the level of improvement from the null model to the best-fit model presented in table 3 or, in other words, the ratio of what the model can explain compared to what there was to explain at the beginning. The final model therefore predicts $27.3 \%$ of the variance of the probability of teaching astronomy at the elementary level in Québec's schools. Also, the Hosmer and Lemeshow goodness-of-fit statistic for the model, including nine independent variables, is not significant $\left(\chi^{2}(8)=11.984, p=.152\right)$, leading us to retain the null hypothesis that the model is a good fit to the data. Finally, testing for residuals, we want to make sure that the standardized residuals follow a normal distribution without too many outliers (Field, 2018). We find only six values whose standardized residuals are located outside the range \pm 1.96 containing $95 \%$ of the distribution of scores (1.2\% of the total sample), three of which have standardized residuals outside the range \pm 2.58 containing $99 \%$ of the distribution of scores ( $0.6 \%$ of the sample). Since these percentages of $1.2 \%$ and $0.6 \%$ are well below $5 \%$ and $1 \%$, respectively, and no standardized residual is found outside the range \pm 3.29 , all assumptions of a normal distribution are met, and we can safely claim that the logistic regression model is well adjusted to the data and effectively tells, based on answers to the survey questions related to the nine variables included in the model, which elementary teachers belong to the Astronomy and Non-astronomy groups, respectively. 
Table 3. Logistic regression model for the dependent variable Astro vs Non Astro (statistically significant predictor variables are highlighted and identified by numbers in square brackets)

\begin{tabular}{|c|c|c|c|c|}
\hline \multirow[b]{2}{*}{ Predictor Variable } & \multirow[b]{2}{*}{$\mathrm{B}(\mathrm{SE})$} & \multicolumn{3}{|c|}{ 95\% CI for Odds Ratio } \\
\hline & & Lower & $\begin{array}{l}\text { Odds Ratio } \\
(\exp (B))\end{array}$ & Upper \\
\hline Constant & $\begin{array}{c}-3.061^{* * *} \\
(.815)\end{array}$ & & .047 & \\
\hline Years of Teaching Experience in Elementary School & $\begin{array}{l}.002 \\
(.016)\end{array}$ & .972 & 1.002 & 1.034 \\
\hline Last Course in Physics \& Chemistry & $\begin{array}{c}.084 \\
(.174)\end{array}$ & .774 & 1.087 & 1.528 \\
\hline Last Course in History & $\begin{array}{c}.223 \\
(.163)\end{array}$ & .907 & 1.250 & 1.722 \\
\hline \multicolumn{5}{|l|}{ Class Level (K) [1] } \\
\hline Class Level (grades 1-2) [1] & $\begin{array}{c}1.679^{* * *} \\
(.420)\end{array}$ & 2.356 & 5.363 & 12.209 \\
\hline Class Level (grades 3-4) [1] & $\begin{array}{c}1.809^{* * *} \\
(.422)\end{array}$ & 2.670 & 6.106 & 13.965 \\
\hline Class Level (grades 5-6) [1] & $\begin{array}{l}1.036^{*} \\
(.412)\end{array}$ & 1.257 & 2.817 & 6.311 \\
\hline Class Level (multiple grades) [1] & $\begin{array}{c}2.028^{* * *} \\
(.477)\end{array}$ & 2.985 & 7.597 & 19.332 \\
\hline \multicolumn{5}{|l|}{ Class Type (Regular) [2] } \\
\hline Class Type (Poor, Immigration) [2] & $\begin{array}{l}-.793^{* *} \\
(.297)\end{array}$ & .253 & .452 & .810 \\
\hline Class Type (Disabilities) [2] & $\begin{array}{l}-.603^{*} \\
(.266)\end{array}$ & .325 & .547 & .922 \\
\hline Teaching Part Time [3] & $\begin{array}{l}-.915^{*} \\
(.357)\end{array}$ & .199 & .400 & .807 \\
\hline Number of Hours of Science Teaching per Week [4] & $\begin{array}{l}.317^{*} \\
(.144)\end{array}$ & 1.034 & 1.372 & 1.821 \\
\hline $\begin{array}{l}\text { Satisfaction Toward Pre-service Training in Astronomy } \\
\text { [5] }\end{array}$ & $\begin{array}{l}.704^{* * *} \\
(.136)\end{array}$ & 1.549 & 2.023 & 2.641 \\
\hline $\begin{array}{l}\text { Satisfaction Toward Pre-service Training in Science } \\
\text { Teaching }\end{array}$ & $\begin{array}{l}-.232 \\
(.121)\end{array}$ & .626 & .793 & 1.005 \\
\hline Previous Science Job & $\begin{array}{r}.817 \\
(.465)\end{array}$ & .910 & 2.263 & 5.632 \\
\hline Participation in Science Leisure Activity & $\begin{array}{r}.376 \\
(.346)\end{array}$ & .740 & 1.457 & 2.868 \\
\hline Participation in In-service Training in Astronomy [6] & $\begin{array}{c}1.187^{* * *} \\
(.236)\end{array}$ & 2.062 & 3.276 & 5.205 \\
\hline Number of Hours of In-service Training Needed [7] & $\begin{array}{c}-.063^{* *} \\
(.022)\end{array}$ & .899 & .939 & .980 \\
\hline Efficacy of In-service Training in Astronomy [8] & $\begin{array}{r}.279^{*} \\
(.119)\end{array}$ & 1.048 & 1.322 & 1.667 \\
\hline Prefer not to Teach Astronomy [9] & $\begin{array}{c}-1.614^{* * *} \\
(.351) \\
\end{array}$ & .100 & .199 & .396 \\
\hline
\end{tabular}

Wald statistic's significance level: * $\mathrm{p}<.05, * * \mathrm{p}<.01, * * * \mathrm{p}<.001$

Pseudo $\mathrm{R}^{2}=.273$.

The significance level of the Wald statistic (noted with one to three asterisms after the value of B in Table 3) indicates which predictor variables do have a significant effect on the outcome (i.e. their regression coefficient is significantly different from zero) and those who don't. One can also see that predictor variables whose contribution is not significant have a $95 \%$ confidence interval for the odds ratio $\exp (\mathrm{B})$ that crosses the value of 1 . It turns out that Years of Teaching Experience in Elementary School, Last Course in Physics \& Chemistry, and Last Course in History do not contribute significantly to the model. The same goes for the variables Satisfaction Toward Pre-service Training in Science 
Teaching, Previous Science Job and Participation in Science Leisure Activity. All other predictor variables (nine in total) are contributing significantly to the model. We describe their contributions below.

Readers should be aware that, as Niu (2018) correctly noted in a review of logistic regression used in educational research, $\exp (\mathrm{B})$ is not a ratio of probabilities (sometimes called relative risk or risk ratio), nor should it be interpreted in terms of probabilities. $\operatorname{Exp}(B)$, the exponential of the logit function, represents the ratio between two odds. As such, the odds ratio $\exp (\mathrm{B})$ represents the ratio of the odds of an event (binary dependent variable) for two individuals differing by one-unit of an independent variable. Factors in a logistic regression should thus be reported not as probabilities nor as effect sizes, but as a difference in odds, as demonstrated below.

Class Level is a nominal categorical variable; hence, the odds ratio (OR) associated with Class Level (grades 1-2) up to Class Level (multiple grades) must be compared with Class Level (kindergarten). In every case, the odds ratios are positive, meaning that the odds that a teacher in grades 1-2 teaches astronomy in his or her classroom is 5.4 higher (figures rounded to the first decimal) than for a teacher in kindergarten; the same goes for grades 3-4 $(\mathrm{OR}=6.1)$, grades 5-6 $(\mathrm{OR}=2.8)$, and multiple grades $(\mathrm{OR}=7.6)$. Class Type is another nominal categorical variable, comparing classes with children from poor socioeconomic background and immigration, and classes with children with disabilities, to regular classrooms. In this case, B is negative and the odds ratios are smaller than one, meaning an inverse relationship: the odds that a teacher in classroom comprising children with disabilities $(\mathrm{OR}=0.5)$ and children of poor or immigration background $(\mathrm{OR}=0.5)$ teaches astronomy to his or her students are smaller than for teachers in regular classrooms.

Other results show that the odds that a part-time teacher teaches astronomy are smaller $(\mathrm{OR}=0.4)$ than for a full-time teacher. The odds of teaching astronomy increase with the number of hours of science teaching per week $(\mathrm{OR}=1.4)$, and with the level of satisfaction toward pre-service training in astronomy $(\mathrm{OR}=2.2)$. Also, the odds that a teacher having participated in in-service training in astronomy does teach astronomy are larger than for one who hasn't (OR $=3.3$ ). The odds of teaching astronomy decrease with the number of hours of in-service training that a teacher thinks he or she needs in order to be able to teach astronomy effectively $(\mathrm{OR}=0.9)$, but increases with the perceived efficacy of in-service training in astronomy $(\mathrm{OR}=1.3)$. Finally, the odds that a teacher who would prefer not to teach astronomy in his or her classroom teaches astronomy is smaller $(\mathrm{OR}=0.2)$ than for a teacher who don't mind teaching this topic in class.

\section{DISCUSSION AND CONCLUSION}

By comparing answers from Astronomy and Non-Astronomy teachers to a series of questions contained in an online survey about astronomy teaching in Québec's elementary schools, we have built a logistic regression model for the binary dependent variable Astro vs Non Astro, and identified nine predictor variables, each associated with a single question in the survey, that contribute significantly to the model. Each of these variables can be considered a factor that is linked to an elementary teacher's decision to teach astronomy or not in his or her classroom.

We were not surprised to find that class level (K-6) and class type (regular, poor and immigration, disabilities) both influence the odds that a teacher teaches astronomy to his or her class. Teachers in elementary cycles 1, 2 and 3 (grades 1 to 6 ) and teachers in multilevel classrooms are more likely to teach astronomy that those in kindergarten. In a sense, this reflects well the distribution of astronomical content in Québec's elementary curriculum, where astronomical topics are distributed in Cycles 1, 2 and 3, but are not present in kindergarten. Astronomy teaching in grades 5 and 6 is also more likely than in kindergarten, but relatively less so than in other grades (smaller odds ratio), a result that is probably due to the fact that, at the end of elementary school (cycle 3), teachers prepare their students for the end-ofyear, province-wide Ministry of Education exams in French and Math, and are thus less likely to make time for astronomy teaching in the class schedule (note that no such exam exists in science at the elementary level in Québec).

As for class type, we find that the odds of astronomy teaching decreases in classes with poor students, students with an immigration background, and students with disabilities, all compared to a regular classroom. It is probable that teachers working with students that are economically, physically or intellectually disadvantaged will concentrate on core subjects, like French and Math, at the expense of astronomy. The same can be said about part-time teachers, that 
usually stay only a few days or weeks in the same classroom before moving on to another class or another school, compared with a full-time teacher that has plenty of time during the school year to plan ahead the teaching of astronomical content to his or her students.

It is also consistent with our initial predictions (see Table 2) that teachers already teaching more science in their classroom will teach more astronomy, and that the few who have received pre-service training in astronomy, and were satisfied with it, will teach more astronomical topics in their classroom.

Finally, we find that teachers who participated in in-service training in astronomy, and teachers that were satisfied with this in-service training, are more likely to teach astronomy to their students. This is exactly what was expected when we introduced these two variables in the model. We also predicted that teachers who declare that they would need more hours of in-service training in astronomy to feel comfortable teaching this topic, as well as those who would rather not teach astronomy, would be less likely to teach this topic to their students. These two variables might illustrate a lack of confidence or feeling of incompetence on the part of the teachers toward astronomy teaching.

Among the variables that do not contribute significantly to the model, we were surprised to find that the four that had to do with previous training and general interest in science (Last Course in Physics, Satisfaction Toward Pre-service Training in Science Teaching, Previous Science Job, and Participation in Science Leisure Activity) did not influence the model. This goes to show that, contrary to our expectations (also voiced by Rowell and Ebbers (2004) and Banilower et al., 2013), a solid background in science and in science teaching before becoming a teacher does not seem to be an essential prerequisite to teach astronomy at the elementary level. By the same logic, Last Course in History, representing a formation in the humanities instead of natural sciences, do not seem to hinder astronomy teaching either.

Finally, in the case of Years of Teaching Experience in Elementary School, our initial prediction was that it could have been either conducive to astronomy teaching or not, depending on the interplay between having more years of experience, but no pre-service training in astronomy (because training was completed before the introduction of astronomy in the curriculum), or less experience, but with pre-service training in astronomy (as the teachers prep schools adapted to the new curriculum since astronomy was introduced). The lack of significance of the result in the logistic regression model may indicate that antagonistic tendencies between years of teaching experience and having received pre-service training in astronomy or not are present in our data and cancel each other out. To check if such is the case, we ran a second logistic regression with the same variables as previously described (Table 3), but added a new one representing the interaction between Years of Teaching Experience in Elementary School and Satisfaction Toward Pre-service Training in Astronomy, on the basis that this interaction might help sort out contributions by both. Unfortunately, this new variable was not contributing significantly to the model $(\mathrm{p}=.117)$ and had to be rejected.

What can we make of these results in terms of suggestions that might positively influence the decision by elementary teachers to actually teach astronomy in their class? We think that if we view the variables that contribute significantly to the logistic regression model as factors that may facilitate or hinder astronomy teaching at the elementary level in Québec schools, we can make the following propositions (numbers in square brackets refer to the associated predictor variable in the logistic regression model, see Table 3):

- Offer high-quality pre-service training in astronomy to future elementary teachers [5];

- Offer high-quality in-service training in astronomy to actual elementary teachers, with a duration appropriate for their needs $[6,7,8]$;

- Raise the profile of science teaching (and astronomy teaching) in elementary schools, specifically targeting teachers that teach less science in their classroom or would prefer not to teach astronomy in class $[4,9]$;

- Remind teachers in kindergarten and grades 5 and 6 of the importance of astronomy teaching and covering the standards contained in the curriculum for their school level (a province-wide, Ministry of Education exam in science at the end of elementary school might go a long way in attaining that goal) [1]; and

- Help elementary teachers with poor, immigrant and disabled students, and part-time teachers, to realize that astronomy teaching offers many possibilities to raise the level of interest of their students, make connections with other school topics (language, math, etc.) and render school more relevant to them $[2,3]$.

Copyright by author(s); $\underline{\text { CC-BY }}$

The Clute Institute 
To sum up, it follows from our results that the promotion of astronomy teaching at the elementary level should be done through effective pre-service as well as in-service training in astronomy and in science. This conclusion is similar to what Rowell and Ebbers (2004) and Banilower et al. (2013) reported in their respective studies. For example, writing about the effectiveness of in-service training and comparing with results from the 1984 study by Orpwood and Alam, Rowell and Ebbers note that "elementary teachers' perceptions of the effectiveness of in-service programs for school science in their schools or school districts have changed very little over the past 20 years; many teachers suggest that it is ineffective." (2004, p. 62) The authors were also concerned that very few teachers have studied science at the university level (pre-service training), and suggest that in-service programs with duration between 5 and 20 hours per year should address contemporary science to bridge that gap.

In their report, Banilower et al. (2013) state that one of the main factors perceived by a majority of school teachers as promoting effective science instruction at the elementary level is their school and school district's science professional development (PD) policies and practices; time devoted to PD is also seen by teachers as one of the best way to promote science instruction in their classroom. Several science program representatives in elementary schools view inadequate science-related PD opportunities as a serious problem inhibiting science instruction.

Banilower et al. also remark: "it is somewhat surprising that in science, only about half of schools are in districts that organize professional development based on the standards. [This] raises the question of how work to align instruction with standards is being done, if not in professional development." (2013, p. 113) What kind of PD works best? Again, Banilower et al. suggest that "professional development workshops and teacher study groups can provide important opportunities for teachers to deepen their content and pedagogical content knowledge, and to develop skill in using that knowledge for key tasks of teaching, such as analyzing student work to determine what a student does and does not understand. When resources allow, going the next step and offering one-on-one coaching to help teachers improve their practice can be a powerful tool." (2013, p. 47)

We believe that promoting such measures will indeed give elementary teachers the tools and confidence they need to efficiently teach astronomy to their students, and that this will ultimately lead to better astronomy teaching in elementary classrooms across Québec. We also believe that the same measures could be promoted in other jurisdiction (provinces or states) in which astronomy teaching at the elementary level is lacking.

If the measures we are proposing are indeed implemented, it would be interesting and useful to repeat the survey in 5 to 10 years from now, to measure their impact. Also, since the introduction of astronomy in Québec's school curriculum in the mid-2000s, pre-service training programs offered by different universities across the province have been modified to include astronomy; a repeat of the survey in about 10 years will allow us to measure the effectiveness of these new pre-service programs on the population of Québec's elementary teachers.

\section{ACKNOWLEDGEMENTS}

The authors wish to thank Mrs. Jill Vandermeerschen and Mr. Yannick Skelling for their help with the statistical analysis, as well as reviewers of the first draft of this paper for useful suggestions.

\section{AUTHOR BIOGRAPHY}

Pierre Chastenay holds a M.Sc. in astrophysics from Université Laval and a Ph.D. in science education from Université de Montréal. After 25 years as director of education at the Planétarium de Montréal, he is now a professor of science education at Université du Québec à Montréal, where his main research interests are science and astronomy education, and elementary teachers training. In 2017, he was awarded the Qilak Prize from the Canadian Astronomical Society and the Sandford-Fleming Medal from the Royal Canadian Institute for Science, recognizing his long and distinguished record of outstanding contributions to communicating astronomy and science to Canadians. His email is: chastenay.pierre@uqam.ca (corresponding author)

Martin Riopel holds a M.Sc. in astrophysics and a Ph.D. in science education from Université de Montréal. He is a professor at Université du Québec à Montréal and a member of the EREST team, where his main research interests 
are science education and technology enhanced learning. In 2013, he was awarded the Excellence in Teaching Award from the Réseau de l’Université du Québec. His email is: riopel.martin@uqam.ca

\section{REFERENCES}

American Association for the Advancement of Science (1990). Science for all americans. New York, NY: Oxford University Press.

Banilower, E. R., Smith, P. S., Weiss, I. R., Malzahn, K. A., Campbell, K. M., \& Weis, A. M. (2013). Report of the 2012 national survey of science and mathematics education. Chapel Hill: Horizon Research Inc.

Bowerman, B. L., \& O'Connell, R. T. (1990). Linear statistical models: An applied approach (2 ${ }^{\text {nd }}$ edition). Belmont, CA: Duxbury.

Chastenay, P. (2014). The state of astronomy teaching in Québec's primary and elementary schools: A survey of teachers. Journal and Review of Astronomy Education and Outreach, 1(2), A3-A40.

Chastenay, P. (2018). To teach or not to teach astronomy, that is the question: Results of a survey of Québec's elementary teachers. Journal of Astronomy and Earth Science Education, 5(2), 115-136. https://doi.org/10.19030/jaese.v5i2.10221

Cohen, J. (1988). Statistical power analysis for the behavioral sciences ( $2^{\text {nd }}$ edition). NewYork, NY: Routledge.

Cohen, J. (1992). A power primer. Psychological Bulletin, 112(1), 155-159.

Conseil des ministres de l'éducation du Canada (1997). Le cadre commun de résultats d'apprentissage en sciences de la nature $M$ à 12. Retreived from http://science.cmec.ca/framework/Pages/french/table.html

Field, A. (2018). Discovering statistics using IBM SPSS statistics ( $5^{\text {th }}$ edition). London, UK: Sage.

Hasni, A., Moreseli, C., Samson, G., \& Owen, M.-E. (2009). Points de vue d'enseignants de sciences au premier cycle du secondaire sur les manuels scolaires dans le contexte de l'implantation des nouveaux programmes au Québec. Revue des sciences de l'éducation, 35(2), 83-105.

Hosmer, D. W., \& Lemeshow, S. (1989). Applied logistic regression. New York, NY: Wiley.

Howell, D. C. (2006). Statistical methods for psychology (6 ${ }^{\text {th }}$ edition). Belmont, CA: Duxbury.

Jarman, R., \& McAleese, L. (1996). Physics for the star-gazer: Pupils' attitudes to astronomy in the Northern Ireland science curriculum. Physics Education, 31(4), 223-226.

Kesidou, S., \& Roseman, J. E. (2002). How well do middle school science programs measure up? Findings from Project 2061's curriculum review. Journal of Research in Science Teaching, 39(6), 522-549. http://doi.org/10.1002/tea.10035

Krumenaker, L. (2008). High school planetariums-Results of a survey. Planetarian, 37(4), 17.

Krumenaker, L. (2009a). The modern U.S. high school astronomy course, its status and makeup, and the effects of No Child Left Behind. Astronomy Education Review, 8. http://doi.org/10.3847/AER2009042

Krumenaker, L. (2009b). The modern U.S. high school astronomy course, its status and makeup II: Additional results. Astronomy Education Review, 8. http://doi.org/10.3847/AER2009052

Menard, S. (1995). Applied logistic regression analysis. Sage University Paper Series on Quantitative Applications in the Social Sciences, 07-106. Thousand Oaks, CA: Sage.

Ministère de l'Éducation, de l'Enseignement supérieur et de la Recherche (2015). Rapport annuel de gestion 2014-2015. Québec: Gouvernement du Québec. Retreived from https://cdn-contenu.quebec.ca/cdn-contenu/adm/min/education/publicationsadm/rapport-annuel-de-gestion/MEES_RAG_2014-2015.pdf?1554138936

Ministère de l'Éducation, du Loisir et du Sport (2014). Indice de milieu socio-économique (IMSE). Retreived from http://www.education.gouv.qc.ca/enseignants/aide-et-soutien/milieux-defavorises/agir-autrement/indice-de-milieu-socioeconomique-imse/

Ministère de l'Éducation du Québec (2006). Le programme de formation de l'école québécoise, éducation préscolaire, enseignement primaire. Québec: Gouvernement du Québec.

Myers, R. (1990). Classical and modern regression with applications ( $2^{\text {nd }}$ edition). Boston, MA: Duxbury.

Niu, L. (2018). A review of the application of logistic regression in educational research: common issues, implications, and suggestions. Educational Review. http://doi.org/10.1080/00131911.2018.1483892

Orpwood, G. W. F., \& Alam, I. (1984). Science education in Canadian schools. Statistical Database for Canadian Science Education (Volume II). Ottawa: Science Council of Canada.

Peng, C.-Y. J., Lee, K. L., \& Ingersoll, G. M. (2002). An introduction to logistic regression analysis and reporting. The Journal of Educational Research, 96(1), 3-14. https://doi.org/10.1080/00220670209598786

Percy, J. R. (2005). Why astronomy is useful and should be included in the school curriculum. In J. M. Pasachoff \& J. R. Percy (Eds.), Teaching and Learning Astronomy: Effective Strategies for Educators Worldwide (pp. 10-13). Cambridge, UK: Cambridge University Press.

Plummer, J. D., \& Zahm, V. M. (2010). Covering the standards: Astronomy teachers' preparation and beliefs. Astronomy Education Review, 9(1). http://doi.org/10.3847/AER2009077

Rowell, P. M., \& Ebbers, M. (2004). Elementary science education in Alberta schools. Edmonton: Center for Mathematics, Science and Technology Education, University of Alberta.

Copyright by author(s); $\underline{\text { CC-BY }}$ 
Sadler, P. M. (1992). High school astronomy: Characteristics and student learning. In C. Pennypacker (Ed.), Workshop on Hands-on Astronomy for Education. Tucson: World Scientific.

Schleigh, S. P., Slater, S. J., Slater, T. F., \& Stork, D. J. (2015). The new curriculum standards for astronomy in the United States. Revista Latino Americana de Educação em Astronomia-RELEA, 20, 131-151.

Slater, S. J., \& Slater, T. F. (2015). Questioning the fidelity of the Next Generation Science Standards for astronomy and space sciences education. Journal of Astronomy and Earth Sciences Education, 2(1), 51-64.

Slater, S. J., Slater, T. F., \& Olson, J. K. (2009). Survey of K-12 science teachers' educational product needs from planetary scientists. Astronomy Education Review, 8.

Thouin, M. (2015). L'astronomie dans le Programme de formation de l'école québécoise et dans la classe. Vivre le Primaire, 28(1), 47-49.

Trumper, R. (2006). Teaching future teachers basic astronomy concepts-seasonal changes-at a time of reform in science education. Journal of Research in Science Teaching, 43(9), 879-906. http://doi.org/10.1002/tea.20138 